\title{
BACTERIA ASSOCIATED HOLOTHURIANS: THE KEY OF HABITAT PREFERENCE, DIET, AND FUNCTIONS
}

\author{
Ariani Hatmanti ${ }^{1)}$ and Pradina Purwati ${ }^{1)}$ \\ Research Center for Oceanography - Indonesian Institute of Science \\ Jln. Pasir Putih I, Ancol Timur Jakarta Utara
}

\begin{abstract}
An investigation of bacteria as holothurians's feed carried out from May until June 2006 in Medane Bay and Kombal Bay, Lombok, Indonesia. The aims of this study are to know whether holothurians eat bacteria, to observe that bacteria are the key for holothurians' habitat preference, and to understand the functions of bacteria in holothurians intestine. The results showed there are many kind of bacteria in the substrates and inside intestine of sea cucumber. There are no specificity in performance, species and number of bacteria which found in anterior or posterior of intestine, as well in their substrates. Therefore, the holothurians do not choose specific bacteria for their feed. Bacteria are the consequence of substrates ingested. Some of them can be microflora in holothurians intestine. Bacteria inside holothurians produce some enzymes such as protease, amylase and agarase. This function was proven by the increasing of Total Organic Matters (TOM) in their feces. This evidence supporting Wiedmeyer (1992) statement that sea cucumber adds organic matters in the sediment. So this also firm holothurians' function in their habitat, as supplier for organic matters. The conclusion is that bacteria are eaten by holothurians by absorption, bacteria is not the key for microhabitat preference for holothurians, and inside the intestine of holothurians, digestion and degradation are the function of bacteria by producing their enzymes.
\end{abstract}

Keywords: bacteria, holothurians, microhabitat preference, function

\section{INTRODUCTION}

For marine deposit - feeding invertebrates, the distribution of species with different life history strategies has long been known to be correlated with sediment organic concentration. Large populations of opportunistic species are found in sediments with enriched organic concentration, while equilibrium species populate low organic concentration sediments. Differences in both behavioral (e.g. feeding rate) and physiological (e.g. growth rate, reproductive output) adaptations determine the ability of species to establish populations in different environments. By systematically documenting diferences in the way these factors vary as sediment organic concentration varies for both opportunistic and equilibrium species, we can better understand the mechanisms underlying this correlation between sediment organic concentration and species distributions (Linton and Taghon, 2000).

Many publications (Massin, 1982; Michio et al., 2003) explain that depositfeeders holothurians eat bacteria, benthic microalgae, and organics matters associated with substrates. Bacteria can be feed for holothurians, they assumed to be absorbed in holothurians intestine. As we know, many animals feeding on sedimentary deposits are more nutritionally dependent on attached bacteria than on the nonliving organic debris (Mann, 1973). Sedimentary 
bacteria are important in the functioning of benthic ecosystems, in that they are the primary remineralizers of organic matter. Deposit feeders are typically the dominant macrofaunal guild in soft sediments (Jumars, 1993), and ingest bacteria associated with sediments at a high frequency (Thayer, 1983; Wheatcroft et al., 1990).

This research was done to answer the question that bacteria are one of the reasons why the holothurians choose their habitats. Generally, many animals feeding on sedimentary deposits are more nutritionally dependant on attached bacteria than on the nonliving organic debris. Bacteria and foraminifera may be major sources of food for atoll holothurians. The aims of this study are to know whether holothurians eat bacteria, to observe that bacteria population is the key for holothurians' habitat preference, and to understand the functions of bacteria in holothurians intestine. The hypothesis was that bacteria are not the key for holothurians' habitat preference and they have some function inside holothurians.

\section{METHODS}

This research was done in Kombal and Medane Bay, Lombok, Indonesia from May until June 2006. Kombal and Medane Bays are located in West of Lombok Island, $12 \mathrm{~km}$ northern from Senggigi. These bays position are $116^{\circ} 8$ '9,9" - 116 4 '24" BT and $8^{\circ} 25^{\prime} 20,6^{\prime \prime}-8^{\circ} 8^{\prime} 9,9^{\prime \prime}$ LS (Purwati et al., 2008). Figure 1 below showed Lombok Island position in Indonesia archipelago map, while Kombal and Medane Bays location were showed in Figure 2.

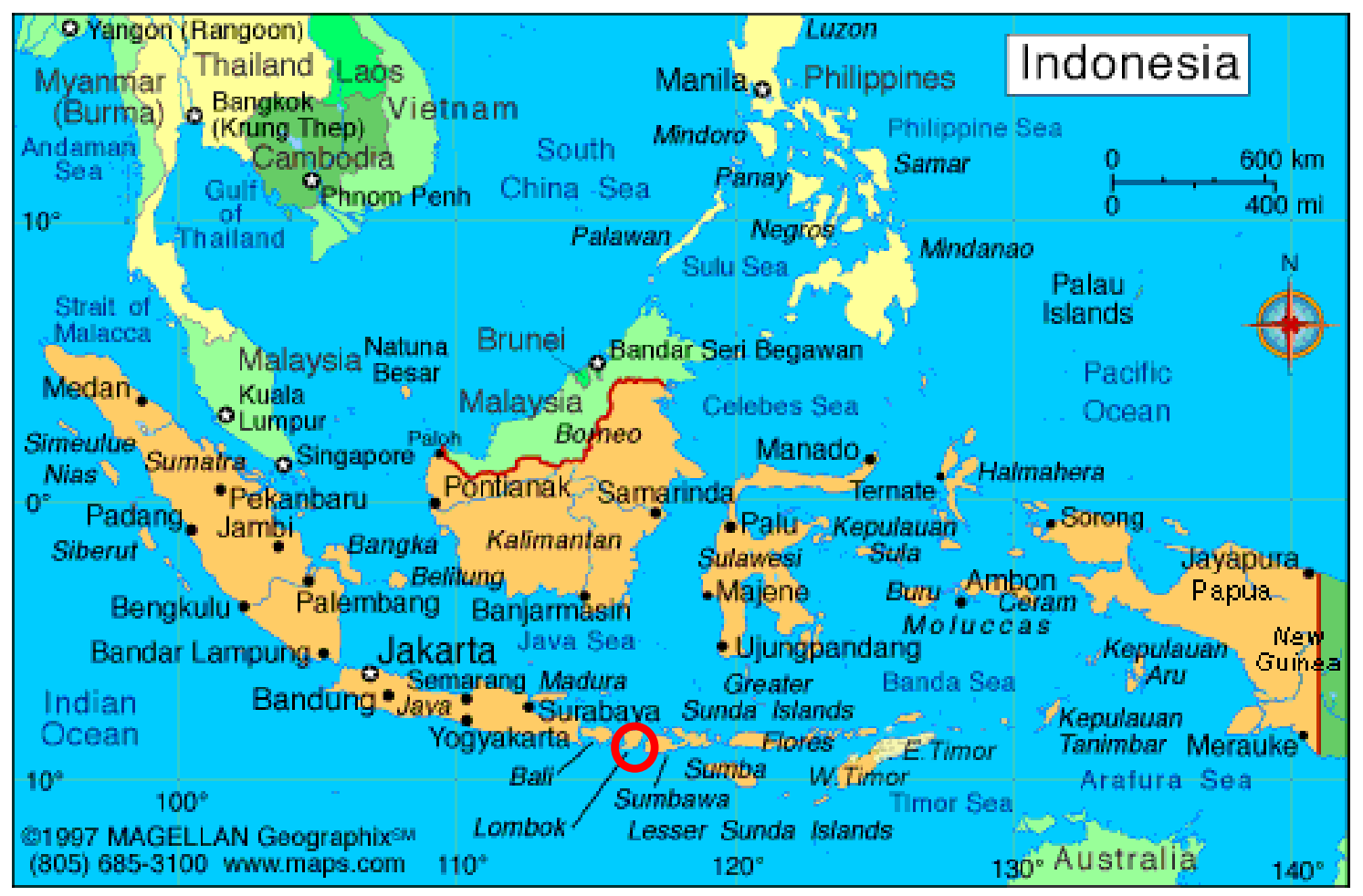

Figure 1. Lombok Island Position (shown in red circle) in Indonesian Archipelago Map 


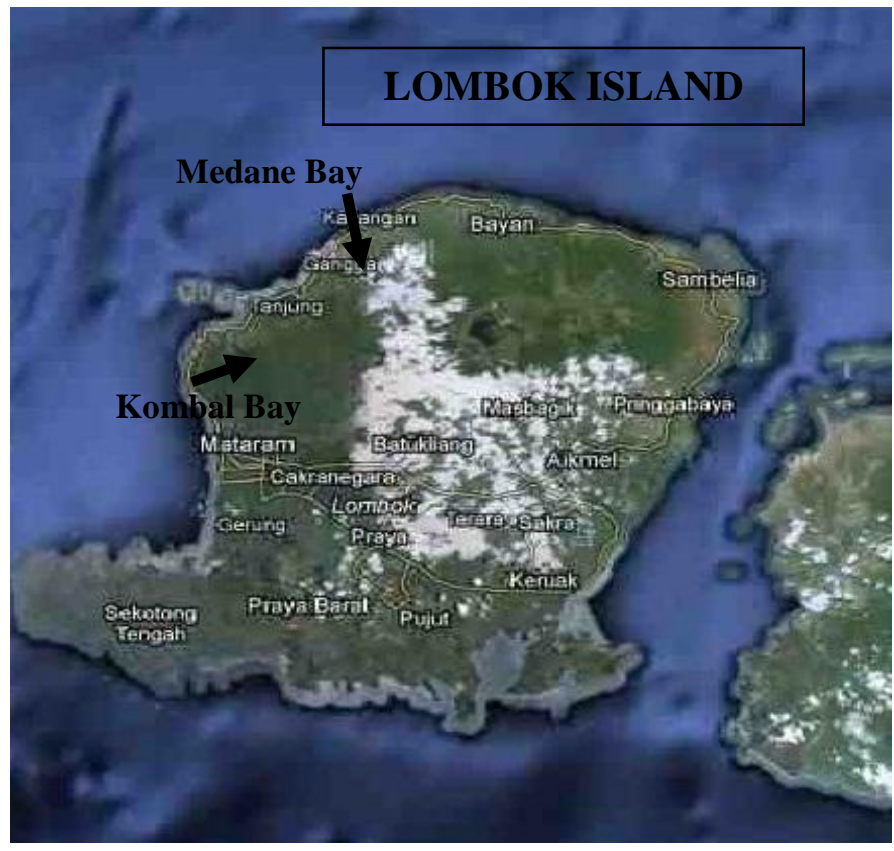

Figure 2. Kombal and Medane Bay Location in Lombok Island

Holothurians were collected at low tide, when the water going to high tide. The holothurians collected was then observed in the laboratory. Observation and description methods were used to analyses the relationship.

Samples were intestine of Holothurian scabra, $H$. atra and $H$. leucospilota and the substrates in front of their tentacles. The intestine was divided into anterior as fore part of the constriction (length was measured) and the posterior as $5 \mathrm{~cm}$ long from the posterior most. Both anterior and posterior of intestine were kept in a sterilized plastic bag, and then used for bacterial analysis. In order to provide selectivity information, sediment which was assumed to be fed was collected. A syringe was embedded $2-3 \mathrm{~cm}$ on the substrate in front of the mouth (in an area of $10 \mathrm{~cm}$ in diameter). Then the sediment was sucked out and the syringe was immediately taken off from the water, and the sediment was pushed into a sterile plastic bag. The samples were analyses by using each 1 gram of the samples (the anterior and posterior of intestine and the substrate) were put in a test tube that fill by $9 \mathrm{ml}$ sterile marine water for dilution from $10^{-1}$ until $10^{-4}$. The $10^{-3}$ and $10^{-4}$ of dilution were put on a petridishes and pour with Nutrient Agar Media, by pour plate method. Those were kept in room temperature for 10 days. The bacteria growth on the NA media were counted by its performance (color, edge, shape, elevation), then purified on the same media. Pure bacteria were identified by Microgen ${ }^{\mathrm{TM}}$ Identification System. Pure bacteria are kept in $-20^{\circ} \mathrm{C}$ glycerol stock for culture collection and further analysis.

Skim Milk Agar (SMA) was used for protease producing bacteria analysis and Soluble Starch Agar (SSA) was used for amylase producing bacteria analysis. The samples were put on the media and kept for 3-5 days until they were analysis. Also pure isolates from Nutrient Agar were streaked on the each media for its analysis. 


\section{RESULTS AND DISCUSSION}

\subsection{Key for Habitat Preference and Diet}

Bacteria can be feed for holothurians, they presumed to be absorbed in holothurians intestine. This study showed that some bacteria were absorbed; it is proved by missing of some bacterial performance in their posterior intestine (Figure 3). Mostly of the bacteria amount decrease in the posterior intestine. It is need to be further analysis whether holothurians do not select bacteria for their feed by its species, but based on its composition of protein.

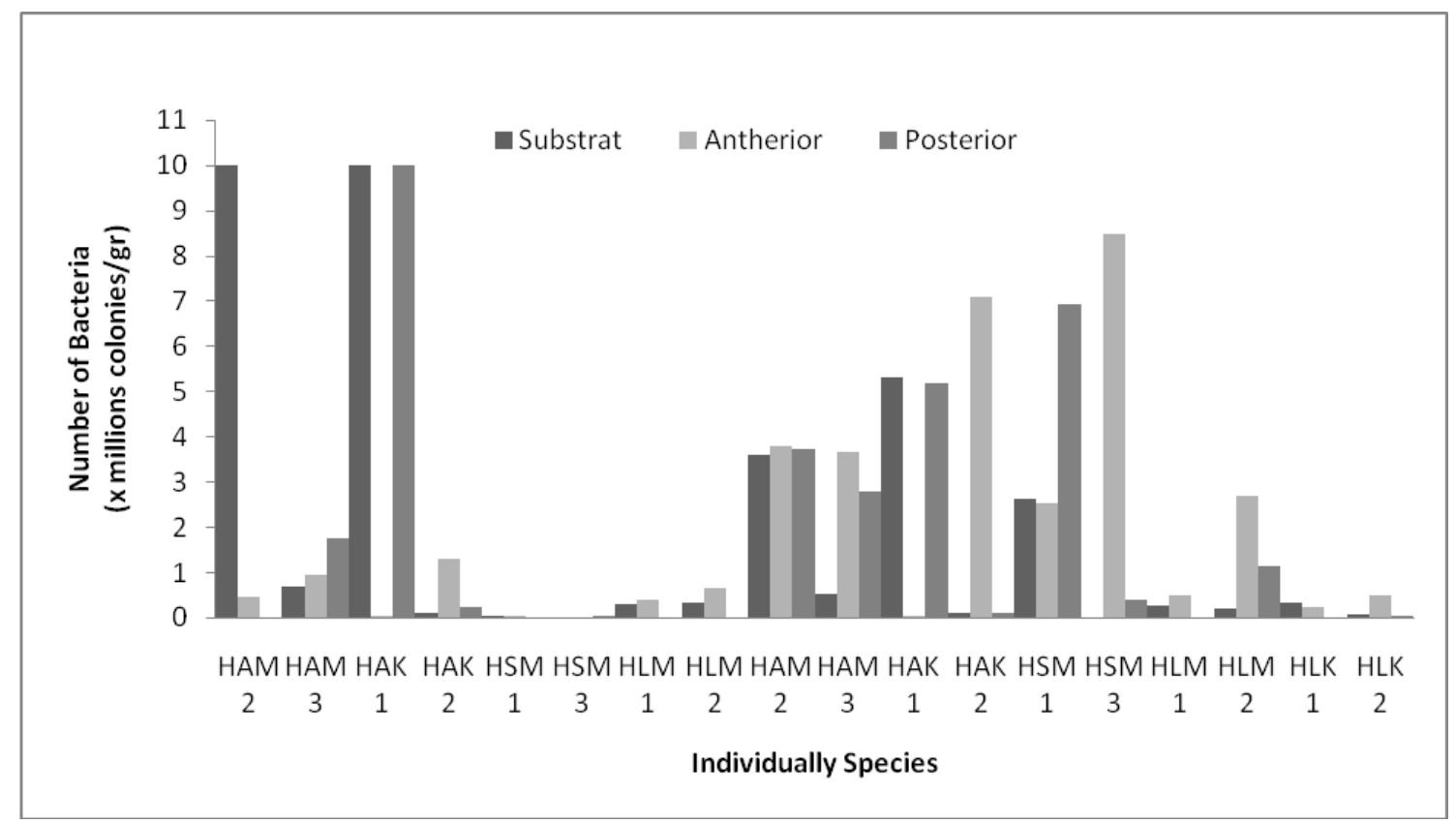

Figure 3. Comparison of number of cream colored, round glossy dome shaped bacteria between individually species in different locations : Holothurian atra Medana (HAM), H. atra Kombal (HAK), H. scabra Medana, H. leucospilota Medana (HLM), H. leucospilota Kombal (HLK)

Thus, the results showed that there are many kind of bacteria in the substrate and inside intestine of sea cucumber. There are no specificity in performance, species, and number of bacteria which found in anterior or posterior of sea cucumber intestine, as well in their substrates. Mean that holothurians do not choose specific bacteria for their feed. This phenomenon results a conclusion that bacteria are not the reason why the holothurians choose a habitat. This microorganism is not the key for microhabitat preference. Bacteria are consequence of substrates ingested.
The results showed that there are a lot of variations on bacterial morphology shown on the plate. But there are unequivocal pattern among substrate, anterior and posterior. This can be shown from the data sorting of each holothurians. In substrate, bacteria more varied than those in intestine, especially for $H$. leucosphilota. Assumed these organisms choose richer habitat than $H$. atra and $H$. scabra. Based on that, variation of bacteria morphological performance in anterior less varied than those in substrate. Holothurians did not select bacteria they ingest from substrate. It can be shown that individually 
holothurians from the same species ate difference bacteria, as shown in their anterior intestine. It is that holothurians filter randomized bacteria for them to eat. Purwati et al. (2006) in their report declared that from Friedmen test there are no preferences of selectivity to particle size of sediment for $H$. atra, but $H$. scabra prefer to soft than hard particles. It is also stated that there is no selectivity of diatoms for their diet.

There is one morphological performance which always be found in holothurians substrate and intestine, such as cream colored with round glossy dome shaped. Figure 3 shows that there are no special pattern of amount of the bacteria, both in substrate and intestine. It is presumed that these bacteria have no meaning to holothurians diets.

\subsection{Functions of Bacteria in Holothurians}

Bacteria in association with holothurians have many functions as well digestion and degradation of its feed, because they produce some enzymes such as protease, amylase and agarase. Some of them can be microflora in holothurians intestine. There are two functions of bacteria inside sea cucumber, that is bacteria absorbed by holothurians as feed, and bacteria which have the ability to degrade organic matters inside their intestine. The

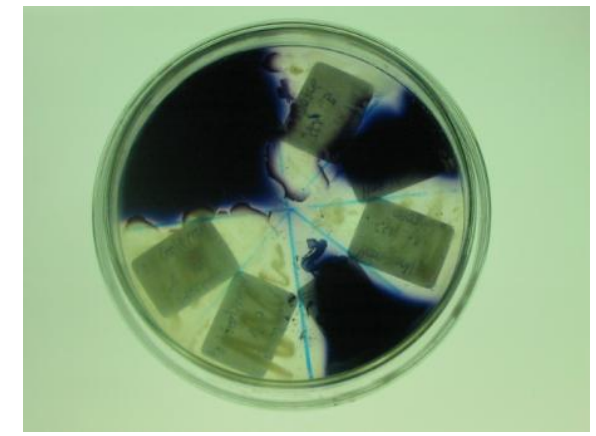

(a) function is related with increasing of Total Organic Matters (TOM) in their fecal pellet. Wiedmeyer (1992) stated that sea cucumber adds organic matters in their environment. Sea cucumbers turn their less nutrient substrate into rich organic matter substrate. It is one of holothurian's benefits to their environment. So this also firm holothurians' function in their habitat, as supplier for organic matters.

Nutrient-degrader bacteria in holothurians's intestine have been proved in this experiment, as well starch and protein degraders. The aim of this experiment was to prove that bacteria are not only their feed, but also have some functions, related to their enzyme. Starch and protein have been selected for substrate tested because they are nutrient sources in great quantities in the sea.

The data show that in $H$. atra $45.5 \%$ bacteria degrade protein (produce protease) and $30.3 \%$ degrade starch (amylase producing bacteria). In $H$. scabra $73.3 \%$ bacteria produce protease but only $13.3 \%$ produce amylase, while in H.leucosphilota $73.7 \%$ are protease producing bacteria and only $26.3 \%$ bacteria produce amylase. Variation percentage between species of holothurians was depending on their substrate composition. Figure 4 shows the ability of bacteria to degrade starch (a) and protein (b).

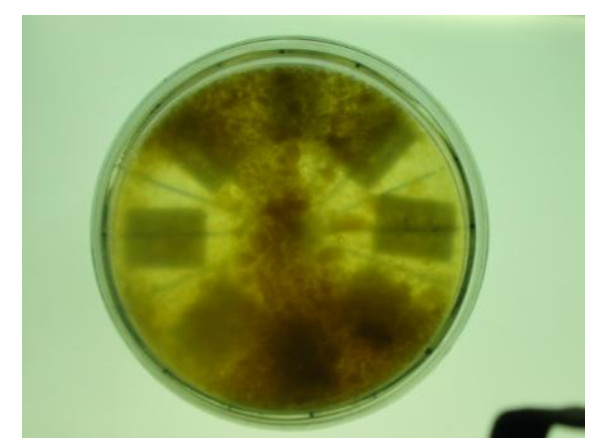

(b)

Figure 4. Picture of starch degrading bacteria (a) and protein degrading bacteria (b). 
Figure 4 (a) point out Starch Soluble Agar (SSA+50\% seawater) which have been grown by bacteria. Clear zone shows that the bacteria produce amylase. Figure 4 (b) shows Skim Milk Agar (SMA+50\%seawater) which have been grown by bacteria. The clear zone refers to protease producing bacteria.

Degrading bacteria were found in sea cucumber intestine with pattern as follows: in $H$. atra those can be found in substrate, anterior and posterior intestine, but mostly in posterior. In H. scabra degrading bacteria can be found in substrate, anterior and posterior. In $H$. leucosphilota amylase and protease producing bacteria were found mostly in substrate. There were two possibility that can be presumed from this statement, first that $H$. leucosphilota prefer bacterial rich substrate, or the second, degrading bacteria compose substrate become organic matter rich substrate which $H$. leucosphilota would like to use for their feed and protection.

For addition, in anterior of $H$. leucosphilota's intestine from Medane Bay, there always be found agar lysis bacteria, even in posterior it can be liquidized agar. The bacteria supposed to have agarase. Assumption that $H$. leucosphilota's substrate was composed of agar like compound as well as karaginan and gelatin can be one of reason the presence of agarase producing bacteria in their intestine. It is strengthen that inside sea cucumber there are substrate-degrading bacteria.

Deposit feeders have been shown to affect bacterial densities (Moriarty et al., 1985; Grossmann \& Reichardt, 1991), growth (Deming \& Colwell, 1982; Plante et al., 1989), activity (Juniper, 1981; Deming \& Colwell, 1982; Aller \& Yingst, 1985), and impact community compositions (Dobbs \& Guckert, 1988; Duchene et al., 1988; Ward-Rainey et al.,
1996). Historically, the relationship between deposit feeders and sedimentary bacteria has been studied in the context of a classic predator-prey $(+,-)$ interaction. We argue here that treatment of deposit-feeder ingestion as a disturbance is more appropriate. Most importantly, it is not clear that digestion of bacteria provides a net gain to deposit feeders (Lopez \& Levinton, 1987; Kemp, 1990). When compared to the typical relationship of a predator and prey, the effect of a deposit feeder on ingested microbes occurs over larger spatial scales, influences communities as opposed to individuals, and is less selective. Moreover, a disturbance disrupts the physical environment as well as biota. Deposit feeding alters geochemical gradients within ingested sediments (Aller, 1982; Plante \& Jumars, 1992), dramatically affects the quantity and architecture of microbial biofilms (Decho \& Lopez, 1993), and can affect grain size, sorting, water content and compaction of sediments (Gray, 1974; Rhoads \& Boyer, 1982).

\section{CONCLUSION}

The bacteria eaten by holothurians were by absorption process, bacteria were not the key for microhabitat preference for holothurians, and inside the intestine of holothurians, digestion and degradation were the function of bacteria by producing their enzymes.

\section{ACKNOWLEDGEMENT}

We are grateful to the Government of Indonesia which supports the Competitive LIPI grant - Census of Marine Life Project where this project includes. 


\section{REFERENCES}

Aller, R.C. 1982. The effects of macrobenthos on chemical properties of marine sediment and overlying water. In: McCall PL, Tevesz MJS (eds) Animal-sediment relations. Plenum Press, New York, p 53-102.

Aller, R.C. and J.Y. Yingst. 1985. Effects of the marine deposit feeders Heteromastus filiformis (Polychaeta), Macoma balthica (Bivalvia), and Tellina texana (Bivalvia) on averaged sedimentary solute transport, reaction rates, and microbial distributions. J. Mar. Res., 43:615-645.

Bakus, G.J. 1968. Defensive mechanisms and ecology of some tropical holothurians. Mar. Bull., 2:23-32.

Decho, A.W. and G.R. Lopez. 1993. Exopolymer microenvironments of microbial flora: multiple and interactive effects on trophic relationships. Limnol. Oceanogr., 38:1633-1645.

Deming, J.W. and R.R. Colwell. 1982. Barophilic growth of bacteria from intestinal tracts of deep-sea invertebrates. Microb. Ecol., 7:85-94.

Dobbs, F.C. and J.B. Guckert. 1988. Microbial food resources of the macrofaunal-deposit feeder Ptychodera bahamensis (Hemichordata: Enteropneusta). Mar. Ecol. Prog. Ser., 45:127-136.

Duchene, J.C., P. Imbaud, and D. Delille. 1988. Associated bacterial microflora of a subantarctic polychaete worm Thelepus setosus. Arch Hydrobiol, 112:221-231.

Gray, J.S. 1974. Animal-sediment relationships. Oceanogr. Mar. Biol. Annu. Rev., 12:223-261.

Gray. J.S. 1966. The attractive factor of intertidal sands to Protodrilus symbioticus. J. Mar. Biol. Assoc., 46:627-646.
Grossmann, S. and W. Reichardt. 1991. Impact of Arenicola marina on bacteria in intertidal sediments. Mar. Ecol. Prog. Ser., 77:85-93.

Jumars, P.A. 1993. Concepts in biological oceanography. Oxford University Press, New York.

Jumars, P.A., D.L. Penry, J.A. Baross, M.J. Perry, and B.W. Frost. 1989. Closing the microbial loop: dissolved carbon pathway toheterotrophic bacteria from incomplete ingestion, digestionand absorption in animals. Deep-Sea Res., 36:483-495.

Linton, D.L. and G.L. Taghon. 2000. Feeding, growth, and fecundity of Abarenicola pacifica in relation to sediment organic concentration. $J$. Exp. Mar. Biol. Ecol., 254:85-107.

Juniper, S.K. 1981. Stimulation of bacterial activity by a deposit feeder in two New Zealand intertidal inlets. Bull. Mar. Sci., 31:691-701.

Kemp, P.F. 1990. The fate of benthic bacterial production. Rev. Aquat. Sci., 2:109-124.

Lopez, G.R. and J.S. Levinton. 1987. Ecology of deposit-feeding animals in marine sediments. Quart. Rev. Biol., 62:235-259.

Mann, K. II. 1973. Macrophyte production and detritus food chains in coastal waters. Mem. Ist. Ital. Idrobiol., 29(suppl.):353-383.

Massin, C. 1982. Food and feeding mechanisms: Holothuroidea. In M. Jangoux and J. M. Lawrence (eds) Echinoderm nutrition. Rotterdam, A. A. Balkema:43-55.

Massin, C. and D. J. W. Lane. 1991. Description of a new species of sea cucumber (Stichopodidae, Holothuroidea, Echinodermata) from eastern Indo Malayan Archipelago: Thelenota rubralineata n. sp. Micronesia, 24(1):57-64. 
Mauliputra, B., S.A.P. Dwiono, and P. Purwati. 2006. Feeding Behaviour of sea cucumber Holothuria atra (Echinodermata: Holothuriidea). Proceeding of Yearly Scientific Meeting of Indonesian Oceanography Scientist Society, Semarang, 19-20 September 2006.

Michio, K. and K. Kurata. 2003. Effects of deposit feeders Stichopus japonicus on algal bloom and organic matter contents of bottom sediments of the enclosed sea. Mar. Poll. Bull., 47:118-125.

Moriarty, D.J.W. 1982. Feeding of Holothuria atra and Stichopus chloronotus on bacteria, organic carbon and organic nitrogen in sediment of the great Barier Reef Australia. J. Mar. Freshwater Res., 33:255-63.

Moriarty, D.J.W., P.C. Pollard, W.G. Hunt., C.M. Moriarty, and T.J. Wassenberg. 1985. Productivity of bacteria and microalgae and the effect of grazing by holothurians in sediment on a coral reef flat. Marine Biology, 85:293-300.

Plante, C.J. and P.A. Jumars. 1992. The microbial environment of marine deposit-feeder guts characterized via microelectrodes. Microb. Ecol. 23:257-277.

Plante, C.J., P.A. Jumars, J.A. Baross. 1989. Rapid bacterial growth in the hindgut of a marine deposit feeder. Microb. Ecol., 18:29-44.

Purwati, P. 2001. Reproduction in Holothuria leucospilota in tropical Darwin waters, NT Australia. Darwin, Northern Territory Univ. $147 p$.

Purwati, P. 2006. Reproductive pattern of Holothuria scabra (Echinodermata : Holothuroidea) in Indonesia Waters. Mar. Res. Indonesia, 30:47-55.

Purwati, P., A.P.D. Sigit, W. Pitra, B.S. Wahyu, K. Edi, and B. Mauliputra.
2008. Timun Laut Lombok Barat (eds : Pradina Purwati dan Augy Syahailatua). Ikatan Sarjana Oseanologi Indonesia - P2O LIPI Lo Tech Aquaculture Australia. 71 pp.

Rhoads, D.C. and L.F. Boyer. 1982. The effects of marine benthos on physical properties of sediment: a successional perspective. In: McCall PL, Tevesz MJS (eds) Animalsediment relations, Vol. 2. The biogenic alteration of sediments. Plenum Press, New York, p 3-52.

Sorokin, J.I. 1971. Population, activity, and production of bacteria in bottom sediments of the central Pacific. Oceanology, 10:853-863.

Thayer, C.W. 1983. Sediment-mediated biological disturbance and the evolution of marine benthos. In: Tevesz MJS, McCall PL (eds) Biotic interactions in recent and fossil communities. Plenum Press, New York, p 479-625.

Trousseller, M., P. Lebanon, B. Baleux, and P. Got. 1993. Spatial Distribution Patterns of Heterotropic Bacterial Populations in a Coastal Ecosystem (Thau Basin, France). Estuarine, Coastal and Shelf Science, 36:281-293.

Wiedmeyer, W.L. 1992. Feeding behaviour of two holothurians Holothuria (Metriatyla) scabra (Jaeger 1833) and $H$ (Haloidema) atra (Jaeger 1833), from Okinawa, Japan. Proceed of the $7^{\text {th }}$ Int. Coral Reef Symp. Guam.

Wilson, D.P. 1955. The role of microorganisms in the settlement of Opheliu bicornis Savigny. J. Mar. Biol. Assoc., 34:531-543.

Ward-Rainey, N., F.A. Rainey, and E. Stackebrandt. 1996. A study of the bacterial flora associated with Holothuria atra. J Exp Mar Biol Ecol 203:11-26. 
Wheatcroft, R.A., P.A. Jumars, C.R. Smith, and A.R.M. Nowell. 1990. A mechanistic view of the particulate biodiffusion coefficient: step lengths, rest periods and transport directions. J. Mar. Res., 48:177-207. 